\title{
Przedsiębiorca właściwy do nabycia własności urządzeń przesyłowych w rozumieniu art. 49 § 2 Kodeksu cywilnego
}

\begin{abstract}
The entrepreneur competent to acquire property of transmission facilities according to the article $49 \S 2$ of the Civil Code: The subject of the article is an attempt to define an entity identified as "an entrepreneur who has connected facilities to its network" within various organizational and legal forms, in which services in the field of water supply and sewage disposal are provided. The author recognises some difficulties in judicial practice when it comes to determination of an entity obliged under Article 49 para. 2 of the Civil Code to acquire property of transmission facilities. In the author's opinion, the determining factor in resolving this matter is the fact which entity owns devices included in the network.
\end{abstract}

Keywords: Civil Code, entrepreneur, property

Słowa kluczowe: Kodeks cywilny, przedsiębiorca, własność

\section{Ekspert ds. legislacji BAS - ilona.szczepanska@sejm.gov.pl •} https://orcid.org/0000-0003-2156-086X

\section{Wstęp}

Zagadnienie podjęte $\mathrm{w}$ niniejszym artykule dotyczy definiowania na gruncie art. $49 \$ 2$ ustawy z 23 kwietnia 1964 r. - Kodeks cywilny (t.j. Dz.U. 2018, poz. 1025, ze zm.; dalej: k.c.) podmiotu właściwego do nabycia własności urządzeń przesyłowych (ze szczególnym uwzględnieniem urządzeń wodociągowych i kanalizacyjnych). Wybór tego tematu uwarunkowany jest dostrzeżonymi w praktyce orzeczniczej trudnościami w zakresie kwalifikacji (właściwego ustalenia) podmiotu zobowiązanego na gruncie art. $49 \$ 2$ k.c. do przejęcia własności urządzeń przesyłowych.

Przywołany przepis przewiduje możliwość wystąpienia wobec „przedsiębiorcy, który przyłączył urządzenia do swojej sieci”, z roszczeniem o nabycie własności urządzeń przesyłowych. Próba zdefiniowana podmiotu właściwego na gruncie art. $49 \$ 2$ k.c. wymaga rozwinięcia problematyki statusu prawnorzeczowego 
urządzeń przesyłowych, o których mowa w art. 49 k.c. (urządzeń wodno-kanalizacyjnych). Zaopatrzenie w wodę i odprowadzanie ścieków należy do zadań własnych gminy związanych z zaspokajaniem zbiorowych potrzeb wspólnoty, za których prawidłową realizację odpowiedzialność ponosi gmina ${ }^{1}$. Szczegółowy zakres obowiązków związanych z zaopatrzeniem w wodę oraz odprowadzaniem ścieków określony został w ustawie z 7 czerwca 2001 r. o zbiorowym zaopatrzeniu w wodę i zbiorowym odprowadzaniu ścieków (t.j. Dz.U. 2018, poz. 1152; dalej: u.z.z.w.). Gospodarka komunalna (w tym w zakresie usług wodno-kanalizacyjnych) świadczona jest przez jednostki samorządu terytorialnego w różnych formach organizacyjno-prawnych. Autorka artykułu podjęła próbę zdefiniowania podmiotu określonego jako „przedsiębiorca, który przyłączył urządzenia do swojej sieci”, w kontekście różnych form organizacyjno-prawnych, w jakich świadczone są usługi w zakresie zaopatrzenia w wodę i odprowadzania ścieków. Uzasadnieniem dla tak postawionego celu są dostrzeżone w praktyce orzeczniczej rozbieżności, a także dość ograniczone wypowiedzi doktryny w tym zakresie. Należy zatem zaznaczyć, że nie chodzi tu o pogłębioną analizę treści art. 49 k.c., ale o skoncentrowanie się na wąskim aspekcie związanym $\mathrm{z}$ ustaleniem zakresu podmiotowego przepisu (oceny, wobec jakiego podmiotu powinno być kierowane określone w przepisie roszczenie). Ponadto, co zostało już wyżej zaznaczone, jakkolwiek art. 49 k.c. odnosi się ogólnie do kategorii urządzeń przesyłowych, to niniejsza analiza odwołuje się w szczególności do urządzeń wodno-kanalizacyjnych² ${ }^{2}$.

\section{Artykuł 49 k.c. - treść przepisu}

1. Artykuł 49 k.c. stanowi: Urządzenia stużace do doprowadzania lub odprowadzania płynów, pary, gazu, energii elektrycznej oraz inne urzadzenia podobne nie należa do części składowych nieruchomości, jeżeli wchodza w skład przedsiębiorstwa ( $\$ 1)$. Paragraf 2 przepisu stanowi: Osoba, która poniosła koszty budowy urządzeń, o których mowa $w \$ 1$, i jest ich właścicielem, może żądać, aby przedsiębiorca, który przyłączył urządzenia do swojej sieci, nabył ich własność za odpowiednim wynagrodzeniem, chyba że $w$ umowie strony postanowity inaczej. $Z \dot{z} a$ daniem przeniesienia własności tych urządzeń może wystąpić także przedsiębiorca.

Artykuł $49 \$ 1$ k.c. obowiązuje w praktycznie niezmienionym kształcie od momentu wejścia w życie Kodeksu cywilnego. W literaturze wskazuje się, że art. 49 k.c. wprowadza wyjątek od reguły zawartej w art. $47 \$ 2$ k.c., wyodrębniając urządzenia

1 J. Jagoda, Komentarz do art. 49 [w:] Ustawa o samorządzie gminnym, red. B. Dolnicki, 2018, LEX.

2 W artykule wykorzystano fragmenty opinii Biura Analiz Sejmowych z 12 lipca 2018 r. w sprawie definicji pojęcia przedsiębiorcy na gruncie art. 49 Kodeksu cywilnego (BAS-WAP 1102/18). 
przesyłowe z części składowych nieruchomości, jeżeli wchodzą one w skład przedsiębiorstwa ${ }^{3}$. Ustawą z 30 maja 2008 r. o zmianie ustawy - Kodeks cywilny oraz niektórych innych ustaw (Dz.U. nr 116, poz. 731) ustawodawca znowelizował art. 49 k.c., dodając do przepisu $\$ 2$ o przywołanej wyżej treści. Nowelizacja miała w założeniu na celu uporządkowanie statusu prawnego urządzeń przesyłowych, przy zapewnieniu odpowiedniego wynagrodzenia osobom, które z własnych środków wybudowały urządzenia i są ich właścicielami. Nowelizacja co do zasady spełniła postulowane założenia, przyznając zarówno właścicielowi urządzenia przesyłowego, o którym mowa w art. $49 \$ 1$ k.c., jak i przedsiębiorcy możliwość żądania zawarcia umowy przenoszącej jego własność (wystąpienia ze stosownym roszczeniem).

Wejście w życie przedmiotowej nowelizacji było reakcją ustawodawcy na pojawiające się rozbieżności dotyczące zasad ustalenia momentu, w którym następuje przejście tytułu prawnego do urządzenia. Problematyka ta na przestrzeni lat była szeroko komentowana $\mathrm{w}$ literaturze oraz omawiana $\mathrm{w}$ orzecznictwie ${ }^{4}$. Ponieważ nie jest to bezpośrednio przedmiot niniejszego artykułu, sygnalizująco jedynie należy wskazać, że poglądy w tym zakresie koncentrowały się przede wszystkim wokół uchwały Trybunału Konstytucyjnego z 4 grudnia 1991 r. (sygn. akt W 4/91) oraz późniejszej uchwały Sądu Najwyższego w składzie 7 sędziów z 8 marca 2006 r. (sygn. akt III CZP 105/05). Trybunał Konstytucyjny (TK) w wydanej uchwale stanął na stanowisku, że urządzenia, o których mowa w art. 49 k.c., stają się przedmiotem własności osoby będącej właścicielem przedsiębiorstwa $\mathrm{z}$ chwilą ich połączenia $\mathrm{w}$ sposób trwały $\mathrm{z}$ siecią urządzeń przedsiębiorstwa ${ }^{5}$. W miarę upływu czasu stanowisko zaprezentowane przez TK było

3 Tak: Ł. Żelechowski, Komentarz do art. 49 [w:] Kodeks cywilny. Komentarz, red. K. Osajda, 2018, Legalis; W.J. Katner, Komentarz do art. 49 [w:] Kodeks cywilny. Komentarz. Część ogólna, red. P. Księżak, M. Pyziak-Szafnicka, 2014, LEX; E. Skowrońska-Bocian, M. Warciński, Komentarz do art. 49 [w:] Kodeks cywilny, t. I, Komentarz. Art. 1-449 ${ }^{10}$, red. K. Pietrzykowski, 2018, Legalis; E. Gniewek, Komentarz do art. 49 [w:] Kodeks cywilny. Komentarz, red. E. Gniewek, P. Machnikowski, 2017, Legalis.

4 Na ten temat m.in. w wyrokach SN z: 23 czerwca 1993 r., sygn. akt I CRN 72/93; 7 listopada 1997 r., sygn. akt II CKN 424/97; 9 października 1998 r., sygn. akt III CKN 641/97; 20 września 2000 r., sygn. akt I CKN 608/99; 31 stycznia 2003 r., sygn. akt IV CKN 1715/00; 3 grudnia 2004 r., sygn. akt IV CZP 347/04. Na ten temat również: A. Olejniczak, Własność urządzeń przyłączonych do sieci przedsiębiorstwa energetycznego (uwagi o wykładni art. 46 k.c.), „Ruch Prawniczy, Ekonomiczny i Socjologiczny” 2000, nr 4; G. Bieniek, Jeszcze w sprawie statusu prawnego urządzeń przesyłowych, „Monitor Prawniczy” 2008, nr 20; G. Matusik, Problem własności urządzeń, o których mowa w art. 49 k.c., „Rejent” 2007, nr 5; M. Zalewski, Wykonywanie praw do urzadzeń przesyłowych (art. 49 k.c.), „Przegląd Sądowy” 2009, nr 5; Z. Kuniewicz, Sytuacja prawna urządzeń przesyłowych wymienionych $w$ art. 49 k.c. [w:] Księga jubileuszowa prof. dr hab. Tadeusza Smyczyńskiego, Toruń 2008, s. 49.

5 Analogiczny pogląd, odwołujący się do wykładni zaprezentowanej przez TK, przedstawił SN m.in. w wyrokach z: 23 czerwca 1993 r., sygn. akt I CRN 72/93; 7 listopada 
coraz częściej krytykowane jako nieprzystające do nowych realiów prawnych ${ }^{6}$. Podsumowaniem tego okresu była uchwała Sądu Najwyższego z 8 marca 2006 r., w której Sąd Najwyższy (SN) stanął na stanowisku, że: art. 49 k.c. nie stanowi samoistnej podstawy prawnej przejścia urzadzeń stużących do doprowadzania lub odprowadzania wody, pary, gazu, pradu elektrycznego oraz innych podobnych urządzeń na własność właściciela przedsiębiorstwa przez ich połączenie z siecia należąca do tego przedsiębiorstwa. Wyrażony przez SN pogląd opierał się na przekonaniu, że wejście wskazanych w przepisie urządzeń w skład przedsiębiorstwa jest jedynie przesłanką ich wyłączenia spod działania zasady superficies solo cedit. Kwestia tytułu prawnego do wspomnianych urządzeń pozostaje natomiast poza zakresem art. 49 k.c. i musi zostać uregulowana w drodze odrębnej czynności prawnej. Stanowisko zaprezentowane w uchwale SN było wyrazem dokonującej się ewolucji w zakresie postrzegania stosunków własnościowych (w tym m.in. gdy chodzi o własność urządzeń przesyłowych) ${ }^{7}$. Skutkiem dokonujących się zmian oraz wydanej uchwały SN była również przywołana już nowelizacja art. 49 k.c. z 2008 r.

W aktualnym stanie prawnym stanowisko odrzucające zasadę automatycznego przejścia własności urządzeń wybudowanych przez odbiorcę usługi z chwilą ich wejścia w skład przedsiębiorstwa w zasadzie nie budzi zastrzeżeń ${ }^{8}$. Urządzenia wodociągowe i kanalizacyjne „wchodzą w skład przedsiębiorstwa” z chwilą ich fizycznego połączenia z siecią. Wtedy też przestają być częścią składową nieruchomości i zachowują status samoistnych rzeczy ruchomych, mogących być przedmiotem odrębnej własności i odrębnego obrotu9. Przez połączenie z sie-

1997 r., sygn. akt II CKN 424/97; 9 października 1998 r., sygn. akt III CKN 641/97; 25 lipca 2003 r. sygn. akt V CK 129/02; 20 września 2000 r., sygn. akt I CKN 608/99 oraz uchwale SN z 13 stycznia 1995 r., sygn. akt III CZP 169/94.

6 Tak wyroki SN z: 26 lutego 2003 r. sygn. akt II CK 40/02; 3 grudnia 2004 r., sygn. akt IV CK 347/04 oraz późniejszy wyrok z 22 stycznia 2010 r., sygn. akt V CSK 206/09. Tak również przedstawiciele doktryny: S. Rudnicki, Glosa do wyroku SN z dnia 3 grudnia 2004 r., IV CZP 347/04, OSP 2005 nr 12; M. Krzyszczak, Własność urządzeń, o których mowa w art. 49 KC, „Monitor Prawniczy” 2000, nr 10; R. Trzaskowski, Z problematyki stosunków własnościowych na tle art. 49 kodeksu cywilnego, „Kwartalnik Prawa Prywatnego" 2001, nr 3.

7 G. Matusik, Własność urządzeń przesyłowych a prawa do gruntu, Warszawa 2011, s. 111.

$8 \quad$ Ibidem, s. 166 i n.; A. Stępień-Sporek, Status prawny urządzeń wskazanych w art. 49 kc, „Monitor Prawniczy” 2008, nr 14; G. Bieniek, Urzadzenia przesyłowe. Problematyka prawna, Warszawa 2008, s. 21-22; E. Skowrońska-Bocian, M. Warciński, Komentarz do art. 49, op. cit.

9 Tak: wyrok SN z 22 stycznia 2010 r., sygn. akt V CSK 195/09; postanowienie SN z 2 grudnia 2015 r., sygn. akt IV CSK 144/15; wyrok Sądu Rejonowego w Pleszewie z 28 października 2015 r., sygn. akt I C 1464/15. 
cią stają się one składnikiem przedsiębiorstwa w rozumieniu art. $55^{1}$ k.c., a tym samym elementem sieci jako zbioru rzeczy (universitas rerum). Sformułowanie „wchodzą w skład przedsiębiorstwa” nie oznacza jednak, że właścicielowi przedsiębiorstwa musi przysługiwać względem przyłączonych urządzeń prawo własności ${ }^{10}$. Zgodnie $\mathrm{z}$ dominującym stanowiskiem prezentowanym $\mathrm{w}$ judykaturze „wejście urządzenia w skład przedsiębiorstwa” jest kwestią faktu, co oznacza, że przesłanka ta jest spełniona $\mathrm{z}$ chwilą podłączenia urządzenia do sieci przedsiębiorstwa $^{11}$. Innymi słowy, ocena, czy urządzenie wchodzi w skład przedsiębiorstwa, odbywa się wyłącznie według kryterium funkcjonalnego, bez znaczenia pozostaje natomiast to, czy, a jeśli tak, to jaki tytuł prawny przysługuje przedsiębiorcy do przyłączonych urządzeń ${ }^{12}$. Natomiast tytuł prawny do urządzeń przesyłowych jest regulowany w drodze odrębnej czynności prawnej i może być to zarówno tytuł prawny wynikający z prawa rzeczowego (własność, użytkowanie), jak i z prawa obligacyjnego (najem, dzierżawa, użyczenie $)^{13}$.

\section{Roszczenie $z$ art. 49 k.c. - stanowisko judykatury wobec podmiotu legitymowanego biernie}

Artykuł $49 \$ 2$ k.c. reguluje natomiast sytuację, w której właściciel urządzenia przesyłowego i przedsiębiorca przesyłowy nie dojdą do porozumienia w zakresie warunków dotyczących korzystania przez przedsiębiorcę z urządzenia. Wówczas, na podstawie wskazanego przepisu, strona, która poniosła koszty budowy urządzeń służących do doprowadzania wody lub odprowadzania ścieków (i jest ich właścicielem), może domagać się przejęcia własności urządzeń za odpowiednim wynagrodzeniem. Artykuł $49 \$ 2$ k.c. wskazuje, że roszczenie właściciela urządzenia przesyłowego (o którym mowa w art. $49 \$ 1$ k.c.) o nabycie własno-

10 Wyrok SN z 22 stycznia 2010 r., sygn. akt V CSK 206/09.

11 Tak: uchwała SN z 8 marca 2006 r., sygn. akt III CZP 105/05; wyrok SN z 7 marca 2014 r., sygn. akt IV CSK 442/13; wyrok Sądu Apelacyjnego w Szczecinie z 20 stycznia 2015, sygn. akt I ACa 635/14. Odmiennie na ten temat (wejście w skład przedsiębiorstwa oznacza, że właścicielowi przedsiębiorstwa przysługiwać musi własność lub inne prawo majątkowe do korzystania z rzeczy): SN w wyroku z 13 maja 2004 r., sygn. akt III SK 39/04.

12 Wyrok Sądu Apelacyjnego w Katowicach z 10 maja 2016 r., sygn. akt V ACa 407/15.

13 Tak: wyrok SN z 26 lutego 2003 r., sygn. akt II CK 40/02; wyrok SN z 13 maja 2004 r., sygn. akt III SK 39/04; wyrok SN z 3 grudnia 2004 r., sygn. akt IV CK 347/04; wyrok SN z 11 lutego 2016 r., sygn. akt V CNP 39/15; wyrok Sądu Apelacyjnego w Szczecinie z 20 stycznia 2015, sygn. akt I ACa 635/14; wyrok Sądu Okręgowego w Szczecinie z 13 stycznia 2017 r., sygn. akt VIII Ga 519/16; wyrok SN z 22 stycznia 2010 r., sygn. akt V CSK 206/09; wyrok SN z 26 lutego 2003 r., sygn. akt II CK 40/02; wyrok SN z 13 maja 2004 r., sygn. akt III SK 39/04. 
ści urządzenia powinno być kierowane wobec „przedsiębiorcy, który przyłączył urządzenia do swojej sieci”. Rodzi się zatem pytanie, czy „przedsiębiorcą, który przyłączył urządzenia do swojej sieci” jest zarazem przedsiębiorca, który prowadzi działalność w zakresie dostarczania wody i odprowadzania ścieków i czy zawsze jest to jeden i ten sam podmiot.

Przed przejściem do analizy tak określonego zagadnienia warto w pierwszej kolejności odwołać się do aktualnego orzecznictwa w tym zakresie. Należy wskazać, że definiowanie pojęcia „przedsiębiorcy, który przyłączył urządzenia do swojej sieci” na gruncie art. $49 \$ 2$ k.c., nie jest jednolite. Stanowisko w sprawie zakresu podmiotowego art. $49 \$ 2$ k.c. zajął również Sąd Najwyższy. W stanie faktycznym będącym kanwą wyroku, usługi w zakresie dostarczania wody i odprowadzania ścieków na rzecz mieszkańców gminy świadczyła spółka mająca osobowość prawną (spółka z o.o.). Spółka odmówiła zawarcia umowy przejęcia odcinka sieci, wskazując, iż nie jest właścicielem sieci, a jedynie eksploatuje sieć. Jednocześnie spółka wskazała gminę (będącą właścicielem sieci) jako podmiot właściwy do przejęcia nowo wybudowanych urządzeń od ich właścicieli. SN wskazał w uzasadnieniu wyroku, że gmina jest objęta hipotezą art. $49 \$ 2$ k.c., jeżeli: sama prowadzi działalność gospodarcza $w$ zakresie zbiorowego zaopatrzenia $w$ wodę lub zbiorowego odprowadzania ścieków i zajmuje się tym jej jednostka organizacyjna nieposiadająca osobowości prawnej ${ }^{14}$. W konsekwencji Sąd Najwyższy uznał, że w analizowanej sprawie podmiotem legitymowanym biernie powinno być przedsiębiorstwo prowadzące usługi wodno-kanalizacyjne. Jako jeden $\mathrm{z}$ argumentów SN wskazał posiadanie odrębnej osobowości prawnej przez podmiot. Podobnie wypowiedział się Sąd Apelacyjny w Krakowie w wyroku z 30 maja 2017 r. (sygn. akt I ACa 1474/16), wskazując, że w sytuacji, gdy innemu podmiotowi przysługuje własność urządzeń, a inny podmiot zarządza nimi w ramach prowadzonej działalności, znaczenie - z punktu widzenia art. 49 k.c. - ma to, kto zarządza siecią i kto dokonał podłączenia urządzenia do sieci. W wyroku tym Sąd Apelacyjny potwierdził zasadność stanowiska zaprezentowanego przez SN, że gmina jest objęta hipotezą art. $49 \$ 2$ k.c. jedynie wówczas, gdy sama prowadzi działalność gospodarczą w zakresie zbiorowego zaopatrzenia w wodę lub zbiorowego odprowadzania ścieków i zajmuje się tym jej jednostka organizacyjna nieposiadająca osobowości prawnej. Natomiast, jeżeli działalność w tym zakresie prowadzi spółka (nawet, jeśli nie przysługuje jej własność owych urządzeń) jest ona podmiotem właściwym do zawarcia umowy o przekazanie własności urządzenia.

Choć w literaturze omawiane zagadnienie nie jest szerzej rozwijane, wydaje się, że aprobująco wobec przedstawionego wyżej stanowiska SN wypowiedział się Ł. Żelechowski, wskazując, iż w sytuacji, gdy gospodarkę wodną prowadzi spółka, która włada wodociągami i przyłącza sfinansowaną przez podmiot trzeci

14 Wyrok SN z 11 lutego 2016 r., sygn. akt V CNP 39/15. 
jego część do eksploatowanej przez siebie sieci, to ona jest podmiotem legitymowanym w sprawie dotyczącej podpisania umowy o przekazanie wybudowanego odcinka sieci ${ }^{15}$. Analogiczne stanowisko przyznające spółce mającej odrębną osobowość prawną legitymację bierną procesową w sprawie dotyczącej roszczenia $\mathrm{z}$ art. $49 \$ 2$ k.c. (w sytuacji, gdy właścicielem sieci jest gmina) prezentowane jest również w orzecznictwie innych sądów powszechnych ${ }^{16}$. Na interpretację art. 49 $\$ 2$ k.c. zaprezentowaną w powyższych orzeczeniach wskazują również wyroki, w których sąd nie dokonuje, co prawda, wprost zdefiniowania podmiotu właściwego do nabycia własności urządzeń przesyłowych, ale podnosi jako decydujący element fakt prowadzenia działalności w zakresie świadczenia usług przez dany podmiot. W orzecznictwie tym wskazuje się, że jeżeli gmina prowadzi działalność w zakresie dostarczania wody lub odprowadzania ścieków w formie gminnego zakładu budżetowego, powództwo powinno być wytoczone przeciwko gminie ${ }^{17}$.

Stanowisko sądów powszechnych w zakresie interpretacji art. $49 \$ 2$ k.c. nie jest jednak jednomyślne. W wyroku z 15 marca 2017 r. Sąd Apelacyjny w Szczecinie uznał, że w sytuacji, gdy właścicielem urządzeń wodociągowo-kanalizacyjnych jest gmina, która wydzierżawiła sieć przedsiębiorstwu, podmiotem właściwym, wobec którego należy wystąpić z roszczeniem $\mathrm{z}$ art. $49 \$ 2$ k.c., jest gmina, nie zaś przedsiębiorstwo świadczące usługi wodno-kanalizacyjne. Argumentując, Sąd Apelacyjny wskazał, że podłączenie do sieci (którego dokonała spółka) stanowi fakt, w wyniku którego wykonane przez powodów fragmenty sieci weszły w skład przedsiębiorstwa, natomiast w dalszym ciągu właścicielem sieci pozostaje gmina ${ }^{18}$. Sądy przychylające się do zaprezentowanej interpretacji stanęły na stanowisku, że legitymowany biernie z art. $49 \$ 2$ k.c. jest podmiot, któremu przysługuje prawo własności do sieci (urządzeń wchodzących w skład sieci). W jednym $\mathrm{z}$ wyroków sąd okręgowy odniósł się zarazem do argumentacji wynikającej z wykładni językowej art. $49 \$ 2$ k.c., wskazując, że taka interpretacja: prowadziłaby [...] do wniosków o niemożności domagania się odpłatnego przejęcia sieci $w$ tych wszystkich gminach, w których przedsiębiorstwo przesyłowe nie istnieje lub wprawdzie istnieje, ale nie jest właścicielem sieci, do której nowo

15 Tak Ł. Żelechowski, Komentarz do art. 49, op. cit.

16 Tak: wyrok Sądu Apelacyjnego w Krakowie z 30 maja 2017 r., sygn. akt I ACa 1474/16; wyrok Sądu Rejonowego w Oleśnicy z 1 grudnia 2014, sygn. akt I C 1596/13; wyrok Sądu Apelacyjnego w Gdańsku z 15 czerwca 2016 r., sygn. akt I ACa 24/16; wyrok Sądu Okręgowego w Elblągu z 2 czerwca 2017 r., sygn. akt I Ca 196/17; wyrok Sądu Rejonowego w Zgorzelcu z 21 listopada 2013 r., sygn. akt I C 172/12; wyrok Sądu Okręgowego w Gliwicach z 4 lutego 2016 r., sygn. akt III Ca 1662/15; wyrok Sądu Okręgowego w Jeleniej Górze z 15 października 2015 r., sygn. akt I C 1459/11.

17 Wyrok Sądu Apelacyjnego w Szczecinie z 4 sierpnia 2015 r., sygn. akt I ACa 259/15; wyrok Sądu Apelacyjnego w Szczecinie z 24 września 2013 r., sygn. akt I ACa 345/13.

18 Wyrok Sądu Apelacyjnego w Szczecinie z 15 marca 2017 r., sygn. akt I ACa 953/16; podobnie wyrok Sądu Rejonowego w Kutnie z 28 grudnia 2017 r., sygn. akt I C 1011/12. 
wybudowane urządzenia zostały przyłaczone ${ }^{19}$. Można również odnaleźć takie orzeczenia, w których przyznanie gminie legitymacji biernej wynika $\mathrm{z}$ dokonanej przez sąd interpretacji art. $49 \$ 2$ k.c. przez pryzmat art. 31 u.z.z.w., który wskazuje, że urządzenia wodociągowe i kanalizacyjne mogą być przekazywane odpłatnie gminie lub przedsiębiorstwu wodociągowo-kanalizacyjnemu ${ }^{20}$.

Na okoliczność, że przedmiotowa problematyka wywołuje trudności interpretacyjne wskazuje również fakt, że w orzecznictwie odnaleźć można wyroki, w których sądy odwoławcze uchylały wyrok sądu pierwszej instancji i przekazywały sprawę do ponownego rozpoznania, podnosząc, że sąd pierwszej instancji nie rozpoznał sprawy co do istoty, ze względu na nierozstrzygnięcie, na potrzeby analizowanej sprawy, pojęcia przedsiębiorcy na gruncie art. $49 \$ 2$ k.c. (co jest kluczową okolicznością dla rozpoznania sprawy) ${ }^{21}$.

Podsumowując ten fragment rozważań, należy wskazać, że analiza orzecznictwa sądów powszechnych wskazuje na brak jednolitości, gdy chodzi o definiowanie podmiotu właściwego do przejęcia własności urządzeń przesyłowych. Stanowisko Sądu Najwyższego oraz przeważająca część orzecznictwa sądów powszechnych wskazuje na rozumienie przedsiębiorcy, o którym mowa w art. $49 \$ 2$ k.c., nie przez pryzmat stosunków własnościowych do sieci (urządzeń należących do sieci), ale z uwagi na prowadzoną działalność w zakresie świadczenia usług wodociągowo-kanalizacyjnych (w tym dokonania przyłączenia urządzeń do sieci). Wydaje się, że wynika to m.in. z wykładni językowej art. $49 \$ 2$ k.c., a także z faktu, iż przepis ten - w przeciwieństwie do art. 31 u.z.z.w. - posługuje się „jedynie” pojęciem przedsiębiorcy (nie wymieniając w przepisie explicite gminy). W ocenie autorki interpretacja taka wydaje się błędna. Należy zgodzić się ze stanowiskiem Sądu Najwyższego zaprezentowanym w uchwale z 13 lipca 2011 r. (sygn. akt III CZP 26/11), w którym wskazano, że art. $49 \$ 2$ k.c. (dodany ustawą nowelizującą z 30 maja 2008 r.), zgodnie z regułą kolizyjną lex posteriori derogat legi priori, derogował normę zawartą w art. 31 ust. 1 u.z.z.w. w zakresie dotyczącym roszczenia o przeniesienie własności urządzeń wodociągowych lub kanalizacyjnych. Wskazany pogląd SN znalazł aprobatę w innych orzeczeniach sądowych ${ }^{22}$.

19 Wyrok Sądu Okręgowego we Wrocławiu z 4 stycznia 2013 r., sygn. akt I C 1247/11; wyrok Sądu Rejonowego w Nidzicy z 27 kwietnia 2017 r., sygn. akt I C 62/15.

20 Tak np. w wyroku Sądu Rejonowego w Nidzicy z 27 kwietnia 2017 r., sygn. akt I C 62/15; wyroku Sądu Rejonowego w Tarnowskich Górach z 2 marca 2015 r., sygn. akt I C 368/14 (interpretacja ta została zakwestionowana przez sąd odwoławczy); wyroku Sądu Okręgowego w Olsztynie z 28 stycznia 2014 r., sygn. akt I C 70/13; wyroku Sądu Rejonowego w Nidzicy z 27 kwietnia 2017 r., sygn. akt I C 62/15.

21 Tak w wyroku Sądu Okręgowego w Poznaniu z 24 marca 2016 r., sygn. akt XV Ca 916/15; wyroku Sądu Okręgowego w Poznaniu z 31 stycznia 2014 r., sygn. akt XV Ca 1632/13.

22 Wyrok Sądu Apelacyjnego w Gdańsku z 20 grudnia 2012 r., sygn. akt V ACa 963/12; wyrok Sądu Apelacyjnego w Poznaniu z 24 kwietnia 2013 r., sygn. akt I ACa 237/13; 


\section{"Przedsiębiorca, który przyłączył urządzenia do swojej sieci" - próba zdefiniowania pojęcia}

Jak wskazują powyższe przykłady, zdefiniowanie podmiotu zobowiązanego do przejęcia własności urządzeń wodociągowo-kanalizacyjnych przysparza w praktyce wiele trudności. Wydaje się, że pomocne w tym zakresie będzie dokonanie rozbioru tak określonej przez ustawodawcę kategorii i zastanowienie się nad poszczególnymi jej elementami. Po pierwsze, ustawodawca wymaga, aby podmiotem legitymowanym w rozumieniu art. $49 \$ 2$ k.c. był przedsiębiorca, po drugie, aby dokonał on przyłączenia urządzeń wodociągowo-kanalizacyjnych, a po trzecie, aby przyłączenie zostało dokonane „do swojej sieci”. Warto odnieść się pokrótce do poszczególnych kwestii.

Przedsiębiorcą, zgodnie $z$ art. $43^{1}$ k.c., jest osoba fizyczna, osoba prawna i jednostka organizacyjna, o której mowa w art. $33^{1} \S 1$, prowadząca we własnym imieniu działalność gospodarczą lub zawodową. W literaturze wskazuje się, że przedsiębiorcą jest również podmiot, który świadczy usługi w zakresie użyteczności publicznej, nawet jeżeli nie mają one charakteru zarobkowego (tzn. nie przynoszą zysku) ${ }^{23}$. W związku z organizacją samorządu terytorialnego po 1989 r. zaspokajanie zbiorowych potrzeb wspólnoty w zakresie zaopatrzenia w wodę i odprowadzania ścieków stało się zadaniem własnym gminy, należącym do zadań z zakresu użyteczności publicznejej ${ }^{24}$ Rozpoczął się wówczas proces komunalizacji dotychczasowych przedsiębiorstw i zakładów usług wodnych. Mocą ustawy z 8 marca 1990 r. o samorządzie terytorialnym (Dz.U. nr 16, poz. 95) oraz ustawy z 10 maja 1990 r. - Przepisy wprowadzające ustawę o samorządzie terytorialnym i ustawę o pracownikach samorządowych (Dz.U. nr 32, poz. 191) urządzenia wodociągowo-kanalizacyjne stały się mieniem poszczególnych gmin (doszło do ich uwłaszczenia przez gminy). Na skutek wejścia w życie wskazanych przepisów przedsiębiorstwa państwowe stały się przedsiębiorstwami komunalnymi, dla których rada gminy miała postanowić o wyborze formy organizacyjno-prawnej. Stąd też świadczenie wskazanych usług dokonuje się w praktyce w różnych formach organizacyjno-prawnych, spośród których najczęściej jest to samorządowy zakład budżetowy lub spółka handlowa (w których gmina jest udziałowcem/ akcjonariuszem), rzadziej dokonuje się to na skutek umowy zawieranej z innym

wyrok Sądu Okręgowego we Wrocławiu z 4 stycznia 2013 r., sygn. akt I C 1247/11; wyrok Sądu Okręgowego w Poznaniu z 31 stycznia 2014 r., sygn. akt XV Ca 1632/13.

23 Tak: Prawo przedsiębiorców [w:] System prawa administracyjnego, t. 8A, Publiczne prawo gospodarcze, red. R. Hauser, Z. Niewiadomski, A. Wróbel, 2018, Legalis, oraz wskazane tam orzecznictwo.

24 Art. 7 ust. 1 pkt 3 ustawy z 8 marca 1990 r. o samorządzie gminnym, t.j. Dz.U. 2018, poz. 994, ze zm.; dalej u.s.g. 
przedsiębiorcą o świadczenie takiej usługi ${ }^{25}$. Zgodnie z art. 9 u.s.g. w celu wykonywania zadań gmina może tworzyć jednostki organizacyjne, a także zawierać umowy z innymi podmiotami. Formy prowadzenia działalności gminnej (w tym wykonywania zadań o charakterze użyteczności publicznej) określone są w ustawie z 20 grudnia 1996 r. o gospodarce komunalnej (t.j. Dz.U. 2017, poz. 827, ze zm.; dalej: u.g.k.). Artykuł 2 przywołanej ustawy wskazuje, że gospodarka komunalna może być prowadzona w szczególności w formie „zakładu budżetowego lub spółek prawa handlowego”. Ponadto jednostka samorządu terytorialnego może powierzyć wykonywanie zadań z zakresu gospodarki komunalnej innym podmiotom (art. 3 u.g.k.). Jak wskazuje się w literaturze, możliwość taka wynika z zasady, że jednostka samorządu terytorialnego ma prawo rozstrzygnąć we własnym zakresie, w jaki sposób prowadzić będzie gospodarkę komunalną w danym obszarze (w tym m.in. w jakiej formie organizacyjno-prawnej) ${ }^{26}$.

Zatem jedną z form prowadzenia gospodarki komunalnej jest prowadzenie jej w formie jednostek organizacyjnych gminy. Może się to dokonywać w formie jednostek budżetowych lub zakładów budżetowych, na co wskazuje zarówno nieobowiązująca już ustawa z 5 stycznia 1991 r. - Prawo budżetowe (Dz.U. nr 4, poz. 18), jak i obowiązujące po jej uchyleniu ustawy o finansach publicznych, w tym obowiązująca ustawa z 27 sierpnia 2009 r. o finansach publicznych (t.j. Dz.U. 2017, poz. 2077, ze zm.). Zakład budżetowy jako forma prowadzenia działalności komunalnej został explicite wskazany w ustawie o gospodarce komunalnej, co, jak się wydaje, wskazuje na to, iż jest to forma preferowana przez ustawodawcę, gdy chodzi o działalność prowadzoną przez jednostki własne gminy ${ }^{27}$. Jednostki budżetowe pokrywają swoje wydatki bezpośrednio z budżetu państwa, a uzyskane dochody odprowadzają do budżetu państwa albo budżetu jednostki samorządu terytorialnego (art. 11 ustawy o finansach publicznych). Z kolei samorządowy zakład budżetowy jest jednostką organizacyjną, która prowadzi działalność gospodarczą na zasadzie odpłatności i pokrywa swoje koszty z dochodów własnych, choć może otrzymywać również dotacje z budżetu jednostki samorządu terytorialnego (art. 15 ustawy o finansach publicznych). Zakład budżetowy jest tworzony i likwidowany w drodze uchwały rady gminy. Nie ma on osobowości prawnej, stąd też wszelką działalność prowadzi w imieniu i na rachunek gminy, choć jest podmiotem wyodrębnionym organizacyjnie, majątkowo i finansowo ${ }^{28}$. W przypadku nieruchomości art. 17 ust. 1 ustawy z 21 sierpnia 1997 r. o gospodarce nieruchomościami (t.j. Dz.U. 2018, poz. 121, ze zm.)

25 NIK, „Utrzymanie i eksploatacja sieci wodociągowych w miastach”, informacja o wynikach kontroli, 2018, s. 8 i 12.

26 C. Banasiński, K. Jaroszyński, Ustawa o gospodarce komunalnej. Komentarz, Warszawa 2017 , s. 34 .

27 Ibidem, s. 52.

28 Ustawa o finansach publicznych. Komentarz, red. W. Misiąg, 2017, Legalis, komentarz do art. 16. 
stanowi, że samorządowe jednostki organizacyjne nieposiadające osobowości prawnej nabywają nieruchomości na własność lub w użytkowanie wieczyste odpowiedniej jednostki samorządu terytorialnego. Artykuł 16 ustawy o finansach publicznych przewiduje, że organ stanowiący jednostki samorządu terytorialnego, tworząc samorządowy zakład budżetowy: wyposaża zakład w środki obrotowe oraz składniki majątkowe przekazane zakładowi w użytkowanie. Użytkowanie jest ograniczonym prawem do rzeczy, mocą którego podmiot uprawniony (użytkownik) uzyskuje prawo do używania rzeczy cudzej i pobierania z niej pożytków (art. 252 k.c.). Powyższe wskazuje zatem, że w przypadku samorządowych jednostek budżetowych oraz samorządowych zakładów budżetowych, mimo iż są one jednostkami wyodrębnionymi organizacyjnie, nie dochodzi w nich do wyodrębnienia funkcji właścicielskiej (właścicielami składników majątkowych są nadal jednostki samorządu terytorialnego ${ }^{29}$. W konsekwencji, jeżeli działalność w zakresie dostarczania wody lub odprowadzania ścieków jest prowadzona w gminie przez samorządowe jednostki organizacyjne nieposiadające osobowości prawnej, podmiotem legitymowanym biernie do wystąpienia $\mathrm{z}$ roszczeniem $\mathrm{z}$ art. $49 \$ 2$ k.c. jest jednostka samorządu terytorialnego (gmina).

Zasady funkcjonowania spółek z udziałem jednostki samorządu terytorialnego (w tym spółek wodociągowo-kanalizacyjnych) zostały określone w ustawie o gospodarce komunalnej, a także w ustawie o samorządzie gminnym. Jak zostało już wyżej przywołane, art. 9 ust. 1 u.s.g. stanowi, że w celu wykonywania zadań gmina może tworzyć jednostki organizacyjne, a także zawierać umowy z innymi podmiotami. Zgodnie z art. 9 u.g.k. jednostki samorządu terytorialnego mogą tworzyć spółki z ograniczoną odpowiedzialnością lub spółki akcyjne oraz przystępować do takich spółek (jeżeli celem spółki jest działalność poza sferą użyteczności publicznej, tworzenie spółek handlowych i przystępowanie do nich jest ograniczone spełnieniem warunków wskazanych w art. 10 u.g.k.). Do niedawna art. 9 ust. 2 u.g.k. przewidywał, że jednostki samorządu terytorialnego mogły (w ramach partnerstwa publiczno-prywatnego) tworzyć także spółki komandytowe i komandytowo-akcyjne. Ustawą z 5 lipca 2018 r. o zmianie ustawy o partnerstwie publiczno-prywatnym oraz niektórych innych ustaw (Dz.U. poz. 1693) ustawodawca uchylił wskazany przepis, pozostawiając możliwość realizacji przedsięwzięcia wyłącznie w formie spółki kapitałowej (o czym mowa szerzej w dalszej części artykułu). Tak więc spółki komunalne stanowią zamknięty katalog form, a ustawa o gospodarce komunalnej wprowadza w tym zakresie szczególne rozwiązania, gdy chodzi o dopuszczalne formy organizacyjne spółek komunalnych ${ }^{30}$.

29 M. Tertelis, Prowadzenie przez jednostki organizacyjne gminy działalności gospodarczej w zakresie zarzadzania nieruchomościami, „Nieruchomości” 2008, nr 1.

30 Tak: C. Banasiński, K. Jaroszyński, Ustawa o gospodarce komunalnej, op. cit., s. 137; K. Byjoch, D. Klimek, Spótka komunalna. Aspekty prawne, ekonomiczne i społeczne, Torun 2015, s. 57. 
Jak zostało już wyżej wskazane, na skutek komunalizacji mienia państwowego dokonanego w 1990 r. gminy nabyły własność takich przedsiębiorstw państwowych oraz prawo do wyboru odpowiednich dla nich form organizacyjno-prawnych. Artykuł 14 u.g.k. stanowi, że przedsiębiorstwa komunalne, w stosunku do których rada gminy do dnia 30 czerwca 1997 r. nie postanowiła o wyborze formy organizacyjno-prawnej lub o ich prywatyzacji, ulegają z dniem 1 lipca 1997 r. przekształceniu w jednoosobową spółkę gminy. Jednoosobowe spółki gminy były $^{31}$ i są ${ }^{32}$ najbardziej popularną (powszechną) formą prowadzenia działalności wodociągowo-kanalizacyjnej. Utworzenie spółki wymaga podjęcia uchwały przez organ stanowiący jednostki samorządu terytorialnego. Artykuł 18 ust. 2 pkt 9 lit. f i g u.s.g. wskazuje, że do wyłącznej właściwości rady gminy należy podejmowanie uchwał w sprawach majątkowych gminy, przekraczających zakres zwykłego zarządu, tj. tworzenia i przystępowania do spółek i spółdzielni oraz rozwiązywania i występowania $\mathrm{z}$ nich, a także określania zasad wnoszenia wkładów oraz cofania i zbywania udziałów i akcji przez wójta. Niezależnie od tego, czy spółka powstała na skutek przekształcenia przedsiębiorstwa państwowego, czy też powstała później do jej utworzenia i funkcjonowania, stosuje się przepisy Kodeksu spółek handlowych. Spółki kapitałowe, o których mowa w art. 9 u.g.k. (tj. spółka z o.o. i spółka akcyjna), wyposażone są w osobowość prawną, przez co następuje wyłączenie odpowiedzialności jednostki samorządu terytorialnego za zobowiązania spółki. Spółka z o.o. może mieć tylko jednego wspólnika, podobnie jak spółka akcyjna - jednego akcjonariusza. Może nim być jednostka samorządu terytorialnego, na co explicite wskazuje art. 12 ust. 4 u.g.k. (wówczas jedyny wspólnik spółki - jednostka samorządu terytorialnego - wykonuje wszystkie uprawnienia przysługujące zgromadzeniu wspólników). Zarówno spółka z o.o., jak i spółka akcyjna są zrzeszeniem (związkiem) podmiotów, tworzącym odrębny byt prawny, powstałym w celu gospodarczym, a z chwilą wpisu do Krajowego Rejestru Sądowego uzyskują osobowość prawną. Spółki prowadzą działalność w sposób samodzielny, będąc autonomiczne zarówno co do spraw wewnętrznych, jak i czynności dokonywanych na rynku. Wpływ jednostki samorządu terytorialnego na spółkę jako udziałowca lub akcjonariusza zostaje zapewniony jedynie za pośrednictwem środków nadzoru właścicielskiego (w tym określanie przedmiotu działalności, obsady personalnej organów spółki) ${ }^{33}$. Jak wskazuje się w literaturze, nadzór właścicielski nad spółkami komunalnymi sprawowany jest w dwóch formach: jako nadzór indywidualny wspólnika wykonywany przez przewodniczącego organu wykonawczego jednostki samorządu terytorialnego

31 T. Aziewicz i in. [w:] Prywatyzacja ustug komunalnych $w$ Polsce, red. T. Aziewicz, Gdańsk 1994, s. 64.

32 GUS, Zmiany strukturalne grup podmiotów gospodarki narodowej w rejestrze REGON, I pótrocze 2018 r., s. 83.

33 C. Banasiński, K. Jaroszyński, Ustawa o gospodarce komunalnej, op. cit., s. 139. 
oraz jako nadzór sprawowany przez rady nadzorcze ${ }^{34}$. Założenie spółki wiąże się z koniecznością wniesienia wkładów do spółki na pokrycie jej kapitału zakładowego. Dzielą się one na wkłady pieniężne oraz wkłady niepieniężne (aporty). Jak stanowi art. $48 \$ 2$ Kodeksu spółek handlowych ${ }^{35}$ : wkład wspólnika może polegać na przeniesieniu lub obciążeniu własności rzeczy lub innych praw, a także na dokonaniu innych świadczeń na rzecz spółki. W formie aportu wniesione mogą być elementy majątku trwałego (nieruchomości, patenty, licencje, urządzenia). Innymi słowy, przedmiotem aportu mogą być: własność, prawa rzeczowe, prawa własności intelektualnej, wierzytelności, akcje lub udziały w spółce, uprawnienia do korzystania z rzeczy lub praw ${ }^{36}$. Składniki wniesione aportem wchodzą w skład majątku spółki (stają się własnością spółki). Na takie rozumowanie wskazuje art. $48 \$ 3$ k.s.h., który stanowi, że prawa, które wspólnik zobowiązuje się wnieść na spółkę, uważa się za przeniesione na spółkę. Znajduje to potwierdzenie w literaturze, gdzie wskazuje się, że jeżeli przepis szczególny lub umowa spółki nie stanowi inaczej, zobowiązanie, to rodzi podwójny skutek ${ }^{37}$. Natomiast z punktu widzenia praw do rzeczy wnoszonych do spółki decydujące znaczenie ma tytuł prawny, na podstawie którego rzecz jest wnoszona. Jeżeli wspólnik wnosi do spółki własność rzeczy, automatycznie przenosi on prawo własności na spółkę, sam natomiast - w rozumieniu prawnym - je traci. Jeżeli zaś wnosi do spółki rzecz jedynie do korzystania z rzeczy, to wspólnik przez cały czas trwania spółki pozostaje jej właścicielem ${ }^{38}$. Jeśli zatem gmina wniesie aportem do spółki wodno-kanalizacyjnej własność urządzeń przesyłowych, to podmiotem właściwym do nabycia nowo przyłączanych urządzeń przesyłowych (w ramach roszczenia $\mathrm{z}$ art. $49 \$ 2$ k.c.) będzie wskazana spółka. Jeżeli natomiast gmina wniesie aportem do spółki prawo do korzystania z rzeczy (użyczenie, najem, dzierżawa), to podmiotem legitymowanym biernie będzie gmina jako właściciel sieci (a precyzyjnie - urządzeń wchodzących w skład sieci).

34 K. Byjoch, D. Klimek, Spółka komunalna, op. cit., s. 183-184. Tak też: Ł. Żabski, Instytucje nadzoru właścicielskiego nad spótkami samorzadowymi, „Prace Naukowe Uniwersytetu we Wrocławiu" 2017, nr 493, s. 194.

35 Ustawa z 15 września 2000 r. - Kodeks spółek handlowych, t.j. Dz.U. 2017, poz. 1577, ze zm.; dalej: k.s.h.

36 Zgodnie z art. $14 \$ 1$ k.s.h. przedmiotem wkładu do spółki kapitałowej nie może być prawo niezbywalne lub świadczenie pracy bądź usług. Dotyczy to np. użytkowania rzeczy, tak: S. Sołtysiński, P. Moskwa [w:] Prawo spółek kapitałowych, red. S. Sołtysiński, Warszawa 2016, s. 73.

37 B. Borowy [w:] Kodeks spółek handlowych. Komentarz, red. Z. Jara, Warszawa 2017, s. 221; A. Kidyba, Komentarz do art. 49 [w:] Komentarz aktualizowany do art. 1-300 ustawy z 15 września 2000 r. Kodeks spółek handlowych, 2018, LEX; K. Kopaczyńska-Pieczniak, Komentarz do art. 49 [w:] Kodeks spółek handlowych, t. I, Komentarz do art. 1-150, red. A. Kidyba, 2017, LEX.

38 B. Borowy [w:] Kodeks spółek handlowych, op. cit., s. 221. 
Podobnie rzecz się ma, gdy wykonywanie zadania własnego gminy zostało przekazane podmiotowi prywatnemu (podmiotowi zewnętrznemu) w formie partnerstwa publiczno-prywatnego (o czym dotychczas stanowił art. 9 ust. 2 u.g.k.). Wskazany przepis przyznawał jednostkom samorządu terytorialnego prawo do prowadzenia gospodarki komunalnej również w formie spółek osobowych (spółki komandytowej i komandytowo-akcyjnej) i odsyłał w tym zakresie do art. 14 ust. 1 ustawy z 19 grudnia 2008 r. o partnerstwie publiczno-prywatnym (t.j. Dz.U. 2017, poz. 1834, ze zm.; dalej: u.p.p.p.). Artykuł 14 ust. 1 u.p.p.p. został znowelizowany przywołaną już wyżej ustawą z 5 lipca 2018 r. o zmianie ustawy o partnerstwie publiczno-prywatnym oraz niektórych innych ustaw w ten sposób, że ustawodawca odszedł od obowiązującej dotychczas zasady, że realizacja przedsięwzięcia między podmiotem publicznym i prywatnym może następować również $\mathrm{w}$ formie wymienionych spółek osobowych, na rzecz realizacji (jedynie) w formie spółek kapitałowych (spółki z o.o. i akcyjnej). Skutkiem dokonanej zmiany było również uchylenie art. 9 ust. 2 u.g.k. Zatem od chwili wejścia w życie ustawy nowelizującej (tj. od 19 września br.) jednostki samorządu terytorialnego nie mogą zakładać spółek komandytowych oraz komandytowo-akcyjnych do prowadzenia gospodarki komunalnej. Natomiast do umów o partnerstwie publiczno-prywatnym zawartych przed dniem wejścia w życie ustawy nowelizującej stosuje się dotychczasowe przepisy u.p.p.p. (art. 22 ustawy nowelizującej). Z tych względów należy przypomnieć, że spółki osobowe (w tym spółka komandytowa i komandytowo-akcyjna) nie mają osobowości prawnej. Jednostka samorządu terytorialnego mogła być wspólnikiem spółki komandytowej jedynie w charakterze komandytariusza. Komandytariusz odpowiada za zobowiązania spółki w sposób ograniczony, tj. do wysokości sumy komandytowej. Podstawowym obowiązkiem wspólnika (w tym komandytariusza) jest wniesienie wkładu (art. 3 k.s.h.). Co do zasady wkład komandytariusza nie może być w wartości niższej niż suma komandytowa (art. $108 \$ 1$ k.s.h.). Wkład komandytariusza może przybrać postać świadczenia pieniężnego lub niepieniężnego. Zatem tak jak w przypadku wkładów do spółek kapitałowych określenie podmiotu właściwego w postępowaniu prowadzonym w trybie art. $49 \$ 2$ k.c. uzależnione jest od tego, czy doszło do przekazania własności urządzeń przesyłowych na rzecz spółki świadczącej usługi wodociągowo-kanalizacyjne, czy też spółka korzysta z owych urządzeń na podstawie innego tytułu prawnego. Podobne zasady znajdą zastosowanie w przypadku powierzania przez jednostki samorządu terytorialnego zadań z zakresu gospodarki komunalnej innym podmiotom w drodze umów cywilnoprawnych.

\section{Podsumowanie}

Na zakończenie należy stwierdzić, że wybór podmiotu właściwego, wobec którego należy wystąpić z roszczeniem, o którym mowa w art. $49 \$ 2$ k.c., uzależ- 
niony jest od tytułu prawnego przysługującego danemu podmiotowi do urządzeń wchodzących w skład sieci. W ocenie autorki decydujące znaczenie dla rozstrzygnięcia owego zagadnienia ma nie tyle forma organizacyjno-prawna, w której prowadzona jest działalność polegająca na dostarczaniu wody i odprowadzaniu ścieków (jak wskazywałaby analiza orzecznictwa), ale to, któremu z podmiotów przysługuje własność urządzeń wchodzących w skład sieci. Trudno sobie bowiem wyobrazić możliwość zawierania przez podmiot umów o nabycie własności urządzenia, jeśli nie jest się właścicielem pozostałych elementów wchodzących w skład sieci. Odstępstwo od tej zasady może dotyczyć jedynie sytuacji, gdy podmiot taki uzyska od właściciela urządzeń wchodzących w skład sieci pełnomocnictwo do dokonywania w imieniu i na rzecz mocodawcy stosownych czynności.

\section{Bibliografia}

Aziewicz T. i in. [w:] Prywatyzacja usług komunalnych w Polsce, red. T. Aziewicz, Gdańsk 1994.

Banasiński C., Jaroszyński K., Ustawa o gospodarce komunalnej. Komentarz, Warszawa 2017.

Bieniek G., Jeszcze w sprawie statusu prawnego urządzeń przesyłowych, „Monitor Prawniczy” 2008.

Borowy B. [w:] Kodeks spółek handlowych. Komentarz, red. Z. Jara, Warszawa 2017.

Byjoch K., Klimek D., Spótka komunalna. Aspekty prawne, ekonomiczne i społeczne, Toruń 2015.

Gniewek E., Komentarz do art. 49 [w:] Kodeks cywilny. Komentarz, red. E. Gniewek, P. Machnikowski, 2017, Legalis.

Jagoda J., Komentarz do art. 49 [w:] Ustawa o samorządzie gminnym, red. B. Dolnicki, 2018, LEX.

Katner W.J., Komentarz do art. 49 [w:] Kodeks cywilny. Komentarz. Część ogólna, red. P. Księżak, M. Pyziak-Szafnicka, 2014, LEX.

Kidyba A., Komentarz do art. 49 [w:] Komentarz aktualizowany do art. 1-300 ustawy z 15 września 2000 r. Kodeks spółek handlowych, 2018, LEX.

Kopaczyńska-Pieczniak K., Komentarz do art. 49 [w:] Kodeks spółek handlowych, t. I, Komentarz do art. 1-150, red. A. Kidyba, 2017, LEX.

Krzyszczak M., Własność urządzeń, o których mowa w art. 49 KC, „Monitor Prawniczy” 2000, nr 10.

Kuniewicz Z., Sytuacja prawna urządzeń przesyłowych wymienionych $w$ art. 49 k.c. [w:] Księga jubileuszowa prof. dr hab. Tadeusza Smyczyńskiego, Toruń 2008.

Matusik G., Problem własności urządzeń, o których mowa w art. 49 k.c., „Rejent” 2007, nr 5.

Matusik G., Własność urządzeń przesyłowych a prawa do gruntu, Warszawa 2011. 
Olejniczak A., Własność urządzeń przyłączonych do sieci przedsiębiorstwa energetycznego (uwagi o wykładni art. 46 k.c.), „Ruch Prawniczy, Ekonomiczny i Socjologiczny” 2000, nr 4.

Prawo przedsiębiorców [w:] System prawa administracyjnego, t. 8A, Publiczne prawo gospodarcze, red. R. Hauser, Z. Niewiadomski, A. Wróbel, 2018, Legalis.

Rudnicki S., Glosa do wyroku SN z dnia 3 grudnia 2004 r., IV CZP 347/04, OSP 2005, nr 12.

Skowrońska-Bocian E., Warciński M., Komentarz do art. 49 [w:] Kodeks cywilny, t. I, Komentarz. Art. 1-449 ${ }^{10}$, red. K. Pietrzykowski, 2018, Legalis.

Sołtysiński S., Moskwa P. [w:] Prawo spółek kapitałowych, red. S. Sołtysiński, Warszawa 2016.

Stępień-Sporek A., Status prawny urządzeń wskazanych $w$ art. 49 kc, „Monitor Prawniczy" 2008, nr 14.

Tertelis M., Prowadzenie przez jednostki organizacyjne gminy działalności gospodarczej w zakresie zarządzania nieruchomościami, „Nieruchomości” 2008, nr 1.

Trzaskowski R., Z problematyki stosunków własnościowych na tle art. 49 kodeksu cywilnego, „Kwartalnik Prawa Prywatnego” 2001, nr 3.

Ustawa o finansach publicznych. Komentarz, red. W. Misiąg, 2017, Legalis.

Zalewski M., Wykonywanie praw do urządzeń przesyłowych (art. 49 k.c.), „Przegląd Sądowy" 2009, nr 5.

Żabski Ł., Instytucje nadzoru właścicielskiego nad spółkami samorządowymi, „Prace Naukowe Uniwersytetu we Wrocławiu” 2017, nr 493, https://doi.org/10.15611/ pn.2017.493.14.

Żelechowski Ł., Komentarz do art. 49 [w:] Kodeks cywilny. Komentarz, red. K. Osajda, 2018, Legalis. 